\title{
PHA Productivity and Yield of Ralstonia eutropha When Intermittently or Continuously Fed a Mixture of Short Chain Fatty Acids
}

\author{
Panchali Chakraborty, ${ }^{1}$ Kasiviswanathan Muthukumarappan, ${ }^{1}$ and William R. Gibbons ${ }^{2}$ \\ ${ }^{1}$ Department of Agricultural and Biosystems Engineering, SAE 225/Box 2120, South Dakota State University, Brookings, \\ SD 57006, USA \\ ${ }^{2}$ Department of Biology and Microbiology, South Dakota State University, Brookings, \\ SD 57006, USA
}

Correspondence should be addressed to Kasiviswanathan Muthukumarappan,muthukum@sdstate.edu

Received 4 June 2012; Revised 1 August 2012; Accepted 2 August 2012

Academic Editor: Anuj K. Chandel

Copyright ( $) 2012$ Panchali Chakraborty et al. This is an open access article distributed under the Creative Commons Attribution License, which permits unrestricted use, distribution, and reproduction in any medium, provided the original work is properly cited.

\begin{abstract}
The research described in this present study was part of a larger effort focused on developing a dual substrate, dual fermentation process to produce Polyhydroxyalkanoate (PHA). The focus of this study was developing and optimizing a strategy for feeding a mixture of SCFAs (simulated ARF) and maximizing PHA production in a cost-effective way. Three different feeding strategies were examined in this study. The substrate evaluated in this study for the growth phase of $R$. eutropha was condensed corn solubles, a low-value byproduct of the dry-mill, corn ethanol industry. The culture was grown to high cell densities in nitrogen-supplemented condensed corn solubles media in $5 \mathrm{~L}$ bioreactors. The overall growth rate of $R$. eutropha was $0.2 \mathrm{~h}^{-1}$. The $20 \mathrm{~mL}$ ARF feeding every $3 \mathrm{~h}$ from 48 to $109 \mathrm{~h}$ strategy gave the best results in terms of PHA production. PHA productivity $\left(0.0697 \mathrm{~g} \mathrm{~L}^{-1} \mathrm{~h}^{-1}\right)$, $\mathrm{PHA}$ concentration $\left(8.37 \mathrm{~g} \mathrm{~L}^{-1}\right)$, and PHA content $(39.52 \%)$ were the highest when ARF was fed every $3 \mathrm{~h}$ for $61 \mathrm{~h}$. This study proved that condensed corn solubles can be potentially used as a growth medium to boost PHA production by R. eutropha thus reducing the overall cost of biopolymer production.
\end{abstract}

\section{Introduction}

Biodegradable polymers made from renewable resources such as agricultural wastes, corn, cassava, tapioca, whey, and so forth, do not lead to depletion of finite resources. The most studied of the biodegradable polymers include polyesters, polylactides, aliphatic polyesters, polysaccharides, and various copolymers [1]. These biopolymers have many of the desirable physical and chemical properties of conventional synthetic polymers [2]. To this point, high production costs have limited the use of biopolymers. However if these costs can be reduced, there would be widespread economic interest [3].

The focus of this project was production of the biopolymer Polyhydroxyalkanoate (PHA) at a low cost. PHA is actually a term used to describe a diverse family of polymers that are composed of 3-hydroxy fatty acid monomers. The carboxyl group of one monomer forms an ester bond with hydroxyl group of the neighboring monomer. Polyhydroxybutyrate (PHB) has been studied in most detail. PHB has good oxygen impermeability, moisture resistance, water insolubility, and optical purity $[4,5]$. Young's modulus and tensile strength of PHB are similar to polypropylene, but elongation at break is $6 \%$ as opposed to that of $400 \%$ for polypropylene [6]. It has good UV resistance, but poor resistance to acids and bases [7]. The oxygen permeability is very low, making $\mathrm{PHB}$ a suitable material for use in packaging oxygen-sensitive products. PHB has low water vapor permeability compared to other bio-based polymers but higher than most standard polyolefins and synthetic 
polyesters $[5,8]$. Since $\mathrm{PHB}$ is toxicologically safe, it can be used for articles which come into contact with skin, feed, or food [9].

In the food industry, PHA has a wide application as edible packaging material, coating agent, flavor delivery agent, and as dairy cream substitute $[10,11]$. It can also be used for making bottles, cosmetics, containers, pens, golf tees, films, adhesives and nonwoven fabrics, toner, and developer compositions, ion-conducting polymers, and as latex for paper coating applications $[12,13]$. It can be used to make laminates with other polymers such as polyvinyl alcohol. The degradation products of PHB are found in large concentrations in human-blood plasma, so is not toxic for human use [14].

PHA production by Ralstonia eutropha (R. eutropha) generally occurs during stationary phase. Hence cells are first grown to high density, after which a key nutrient is limited to trigger PHA synthesis [14]. Because of this dual phase process, PHA production lends itself to fed-batch, as well as, continuous operation. This follows Pontryagin's maximum principle, which is an optimal feeding strategy for fed-batch fermentation [15]. The key to this principle is determining the optimum switching time $\left(t_{c}\right)$. The maximum growth rate $\left(\mu_{\max }\right)$ should be initially maintained, then switched to the critical growth rate $\left(\mu_{c}\right)$ at $t_{c}$ to maximize the specific product production rate $\left(\rho_{\max }\right)$. Since growth rate is affected by Carbon : Nitrogen $(\mathrm{C}: \mathrm{N})$ ratio, it should also be changed at $t_{c}$.

A variety of carbon sources have been used for production of PHA using different fermentation strategies. Carbohydrates, oils, alcohols, fatty acids, and hydrocarbons are potential carbon sources for PHA production. Ethanol byproducts, cane and beet molasses, cheese whey, plant oils, hydrolysates of corn, cellulose, hemicellulose, palm oil, soybean oil, tallow, corn steep liquor, casamino acids, and food scraps had been used as substrates to produce PHA using different organisms [16-21].

The substrate evaluated in this study for the growth phase of R. eutropha was condensed corn solubles (CCS), which is a low-value byproduct of the dry-mill, corn ethanol industry. In the dry mill process, the whole corn is milled, mixed with water, and enzymatically hydrolyzed to convert starch to glucose, which is converted to ethanol by fermentation. After distillation to remove ethanol, the larger corn particles are recovered by centrifugation as distiller's wet grains. The supernatant is condensed in multiple-effect evaporators to give condensed corn solubles [22].

The composition of CCS is shown in Table 1. Cornmilling byproducts are typically marketed as animal feed because of their protein content. However, these byproducts may also contain residual carbohydrates, which might be utilized by microbial fermentation to produce industrial biopolymers. CCS is an excellent source of vitamins and minerals, including phosphorous and potassium.

The objective of this study was to determine the effects of adding artificial rumen fluid (ARF) on cell viability, growth as well as PHA production to a $48 \mathrm{~h}$ culture of $R$. eutropha. Different strategies of feeding simulated ARF into the bioreactors were assessed to maximize PHA production.
TABLE 1: CCS composition from a dry mill ethanol plant.

\begin{tabular}{lc}
\hline Components & CCS \\
\hline Dry matter \% & 34.9 \\
Crude protein \% & 13.7 \\
Crude fat (ether extract) \% & 16.2 \\
Ash \% & 9.5 \\
Crude fiber \% & 0.8 \\
Copper ppm & 8.3 \\
Sodium ppm & 5,620 \\
Calcium ppm & 487 \\
Magnesium ppm & 6,850 \\
Zinc ppm & 49 \\
Phosphorus ppm & 15,400 \\
Potassium ppm & 22,900 \\
\hline
\end{tabular}

Composition is on dry matter basis.

\section{Materials and Methods}

2.1. Culture, Maintenance, and Inoculum Propagation. The ATCC 17699 type strain of $R$. eutropha was used. The culture was routinely transferred to nutrient broth and incubated on a reciprocating shaker $(250 \mathrm{rpm})$ at $30^{\circ} \mathrm{C}$ for $24 \mathrm{~h}$. For short-term maintenance, the culture was stored on Tryptic Soy Agar (TSA) slants covered with mineral oil and stored in the refrigerator. Inoculum for all trials was prepared in a stepwise manner, by transferring the culture from TSA plates into $100 \mathrm{ml}$ of the CCS medium (described below), then incubating for $24 \mathrm{~h}$ on a rotary shaker $(250 \mathrm{rpm})$ at $30^{\circ} \mathrm{C}$. The inoculum rate for all bioreactor trials was $1 \%\left(\mathrm{vv}^{-1}\right)$ from a $24 \mathrm{~h}$ grown culture to an average OD of 1.04 .

2.2. Medium. A low-cost medium based on CCS was developed in a prior study [23]. This medium, containing $240 \mathrm{~g} \mathrm{CCS} \mathrm{L}^{-1}$, with a $\mathrm{C}: \mathrm{N}$ ratio of $50: 1$ was the best medium for the growth of $R$. eutropha. The medium was prepared by mixing $1,370 \mathrm{~mL}$ CCS with $4,630 \mathrm{~mL}$ deionized water, adjusting the $\mathrm{pH}$ to $6.5 \mathrm{using} 10 \mathrm{M}$ sodium hydroxide $(\mathrm{NaOH})$, then centrifuging at $11,000 \mathrm{rpm}$ for $7 \mathrm{~min}$ at $15-$ $25^{\circ} \mathrm{C}$. The supernatant was then filtered through Whatman filter paper \#113 and autoclaved. A filter sterilized $178 \mathrm{~g} \mathrm{~L}^{-1}$ ammonium bicarbonate $\left(\mathrm{NH}_{4} \mathrm{HCO}_{3}\right)$ stock solution was prepared and then $20.4 \mathrm{~mL}$ of this solution was added to each liter of CCS medium to adjust the $C: N$ ratio to $50: 1$. The $\mathrm{pH}$ was further adjusted to 7.0 by adding $10 \mathrm{~N}$ sulfuric acid $\left(\mathrm{H}_{2} \mathrm{SO}_{4}\right)$ before inoculation.

\subsection{Fermentation Conditions for Cultivation of R. eutropha in Bioreactor. Experimental trials were conducted in $5 \mathrm{~L} \mathrm{New}$ Brunswick, Bioflo III, Edison, NJ bioreactor that contained $4 \mathrm{~L}$ of CCS medium. Filter sterilized air $\left(1 \mathrm{~L} \mathrm{~L}^{-1} \mathrm{~min}^{-1}\right)$ was sparged into the bioreactor, and $2-3 \mathrm{~mL}$ of antifoam (Cognis Clerol FBA 5059, Cognis, Cincinnati, OH) were added to the medium before inoculation. Fermentation medium was incubated at $30^{\circ} \mathrm{C}$ and $500 \mathrm{rpm}$ for $48 \mathrm{~h}$, since prior research had shown $R$. eutropha to reach its}


maximum population by this time/temperature combination [23].

At $48 \mathrm{~h}$ we began feeding the fermenter a mixed shortchain fatty acid (SCFA) solution, using any of the three different strategies. This SCFA solution, referred to as ARF, contained 10 parts acetic, 2 parts butyric, 15 parts lactic, and 20 parts propionic acids $\left(\mathrm{v} \mathrm{v}^{-1}\right)$. The composition of ARF was based on a separate study evaluating fermentation of biomass with rumen consortia. A total volume of $372 \mathrm{~mL}$ of ARF was fed to the culture over a period of $48 \mathrm{~h}$. In the first feeding strategy ( $24 \mathrm{~h}$ feeding), $124 \mathrm{~mL}$ of ARF was added at 48,72 , and $96 \mathrm{~h}$. In the second feeding strategy ( $3 \mathrm{~h}$ feeding), $20 \mathrm{~mL}$ ARF was added at $48 \mathrm{~h}$ and then every $3 \mathrm{~h}$ until $109 \mathrm{~h}$. In the third feeding strategy (continuous feeding), ARF was continuously added from 48 to $96 \mathrm{~h}$ at a rate of $7.75 \mathrm{~mL} \mathrm{~h}^{-1}$. All incubations were continued until $144 \mathrm{~h}$. Two replications were performed for each feeding strategy to determine the effect of mixed fatty acids on cell viability, acid utilization, and PHA production.

\subsection{Analytical Methods}

2.4.1. Viable Counts, Cell Dry Weights, pH, HPLC, and Ammonium/Phosphate Analysis. Samples were collected every $12 \mathrm{~h}$ and viable cell counts were done with TSA. At 72, 96, and $144 \mathrm{~h}, 50 \mathrm{~mL}$ samples were collected to determine cell dry weights. Samples were centrifuged and the precipitate was dried in the hot air oven at $80^{\circ} \mathrm{C}$ for 2 days. $\mathrm{pH}$ was measured using an Acumet $950 \mathrm{pH}$ meter (Thermo Fisher Scientific of Waltham, MA). Samples were also analyzed via a Waters HPLC system (Milford, MA) for sugars, organic acids and glycerol. These samples were first filtered through a nonsterile $0.2 \mu \mathrm{m}$ filter to remove solids, and then frozen until analysis. An Aminex HPX $87 \mathrm{H}$ column (BioRad Laboratories, Hercules, CA), operated at $65^{\circ} \mathrm{C}$ with a helium-degassed, $4 \mathrm{mM} \mathrm{H}_{2} \mathrm{SO}_{4}$ mobile phase at a flow rate of $0.6 \mathrm{~mL} \mathrm{~min}^{-1}$ was used. Peaks were detected using a refractive index detector. Standard solutions of maltose, glucose, lactic acid, butyric acid, acetic acid, propionic acid, succinic acid, and glycerol (at 3 and $30 \mathrm{~g} \mathrm{~L}^{-1}$ ) were used to calibrate the integrator. Samples collected at 0, 72, and $120 \mathrm{~h}$ were also tested for ammonia and phosphate using Hach Ammonium and Phosphate Unicell tests (Hach Company, Loveland, Colorado).

2.4.2. PHA Analysis. To measure PHA, $50 \mathrm{~mL}$ samples of broth were collected at 72,96 , and $144 \mathrm{~h}$ and centrifuged. The pellets were then lyophilized and ground using a mortar and pestle. The method developed by Braunegg et al. [24] was used to simultaneously extract and derivatize PHA to the 3-hydroxyalkanoate methyl esters of the monomers. In this method, $20-30 \mathrm{mg}$ of ground cells were digested by adding $5 \mathrm{~mL}$ of digest solution and incubating at $90-100^{\circ} \mathrm{C}$ for $4 \mathrm{~h}$. The digest solution contained $50 \%$ chloroform, $42.5 \%$ methanol, $7.5 \% \mathrm{H}_{2} \mathrm{SO}_{4}\left(\mathrm{vv}^{-1}\right)$. After cooling, sample was washed with $2 \mathrm{~mL}$ of water, and the bottom layer (containing the chloroform and methyl esters of PHA) was collected and placed in a Gas Chromatography (GC) vial with anhydrous sodium sulfate (to remove residual water). Vials were frozen until analysis.

PHA was quantified using a Hewlett-Packard 5890 Series II (Palo Alto, CA) GC with a flame ionization detector (GC-FID) [24, 25]. Split injection was used onto a Supelco SSP-2380 (Park Bellefonte, PA) capillary column $(30 \mathrm{~m} \times$ $0.25 \mathrm{~mm}$ I.D. with $0.20 \mathrm{um}$ film). The inlet head pressure was maintained at $28 \mathrm{psi}$, and the temperature program started at $50^{\circ} \mathrm{C}$ for $4 \mathrm{~min}$, then increased by $3^{\circ} \mathrm{C} \mathrm{min}^{-1}$ to a final temperature of $146^{\circ} \mathrm{C}$ for $4 \mathrm{~min}$. The injector and detector temperatures were $230^{\circ} \mathrm{C}$ and $240^{\circ} \mathrm{C}$, respectively. Purified poly (3-hydroxybutyric acid co-3-hydroxyvaleric acid) $(\mathrm{P}(\mathrm{HB}-\mathrm{HV}))$ obtained from Sigma-Aldrich was used for a standard calibration. The copolymer consisted of $88 \%$ 3-hydroxybutyric acid (3-HB) and 12\% 3-hydroxyvaleric acid (3-HV). Copolymer concentrations of $2-10 \mathrm{mg} \mathrm{mL}^{-1}$ were digested as above, and then analyzed by GC-FID. Retention times were 14.9 min for methylated $3-\mathrm{HB}$, and 17.8 min for methylated 3-HV.

2.5. Statistical Analysis. All trials were performed in duplicates. Various fermentation parameters (maximum cell populations, SCFA utilization rates, PHA productivity, etc.) were analyzed to determine least significant differences between treatments using randomized complete block design. Fermentation efficiency (FE) was calculated as the percentage of substrate supplied to that was consumed. PHA productivity was calculated as the concentration of PHA produced per hour whereas PHA content was determined as a percentage of PHA concentration over cell dry weight. Data were analyzed using the PROC GLM procedure of SAS software to determine $F$ values and least squares (LS) means. Exponential regression equations were used to determine growth rates and acid utilization rates for each replication, from which means were calculated. They were statistically analyzed by ANCOVA to test homogeneity of slopes. Statistical data were analyzed at the significant level of $P<0.05$.

\section{Results}

In all bioreactor trials, the organism was incubated under similar conditions $\left(30^{\circ} \mathrm{C}, 500 \mathrm{rpm}\right.$, and aeration at $1 \mathrm{LL}^{-1} \mathrm{~min}^{-1}$ ) for the first $48 \mathrm{~h}$, and this data was relatively uniform. Figure 1 and Table 2 show the average cell population, growth rate, acid utilization, and ammonia and phosphate uptake rates during this growth period.

Compared to shake flasks trials (Table 3), the maximum cell population in bioreactor trials was almost 10 -fold higher $\left(2.3 \times 10^{10} \mathrm{cfu} \mathrm{mL}^{-1}\right)$. Likewise, the growth rate of R. eutropha was also higher in the bioreactor $\left(0.20 \mathrm{~h}^{-1}\right)$ compared to the aerated shake flasks $\left(0.13 \mathrm{~h}^{-1}\right)$. In the shake flask trials, lactic acid was consumed at the fastest rate followed by acetic, butyric, succinic, and propionic acids. In the bioreactors, the organic acid utilization rates in the growth phase were generally similar to shake flask trials except for lactic acid. It was consumed slower than acetic acid. Overall acid utilization rates were higher in the bioreactors than in shake flasks probably due to the higher cell population. Percentage 
TABLE 2: Average growth and nutrient utilization rates of $R$. eutropha in CCS medium through 48 h in biorector.

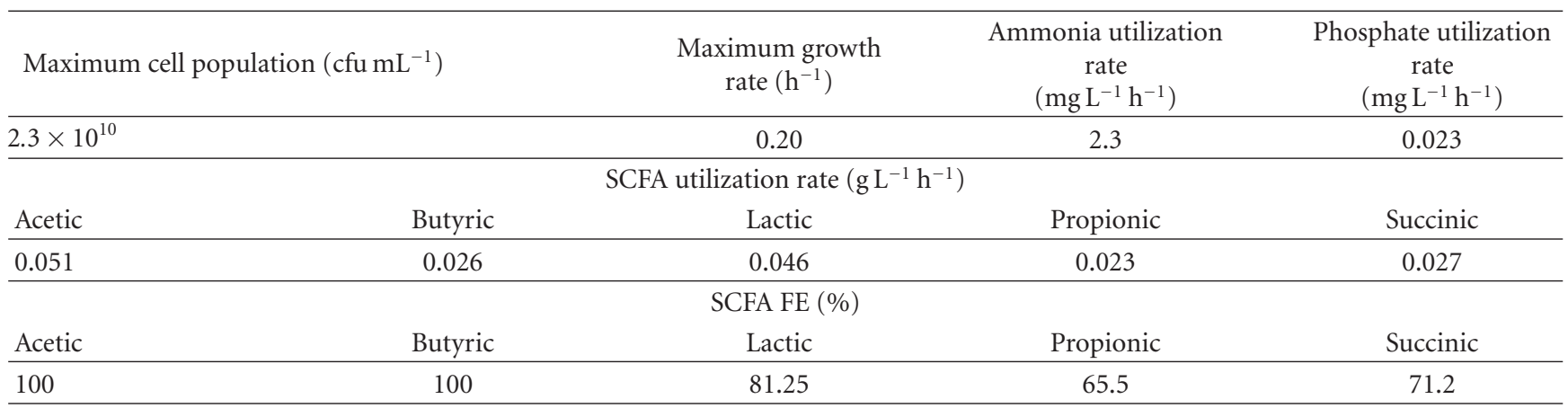

TABLE 3: Average growth and nutrient utilization rates of R. eutropha in CCS medium through $48 \mathrm{~h}$ in shake flasks.

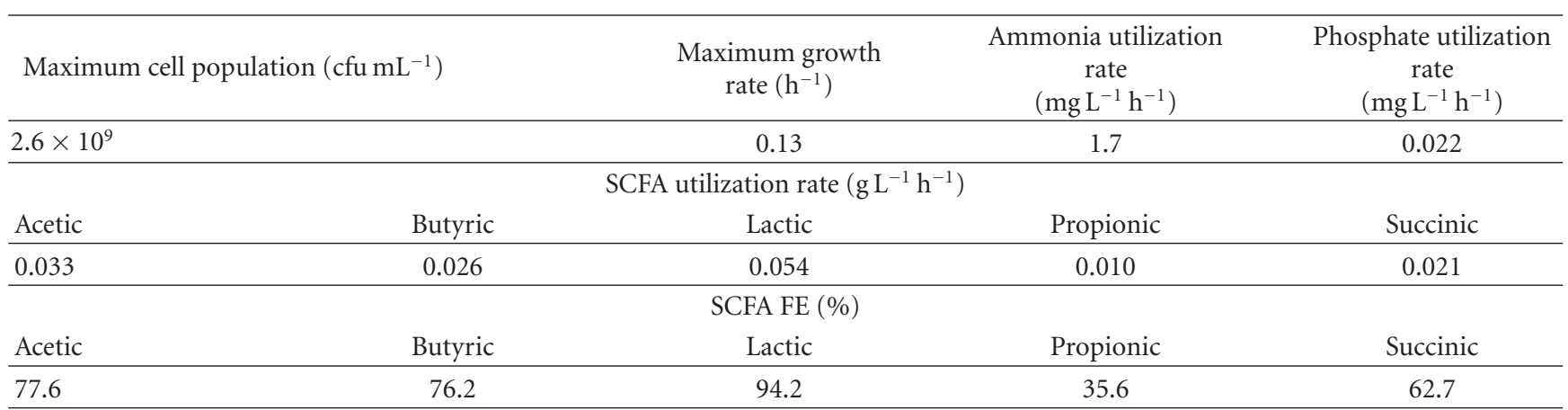

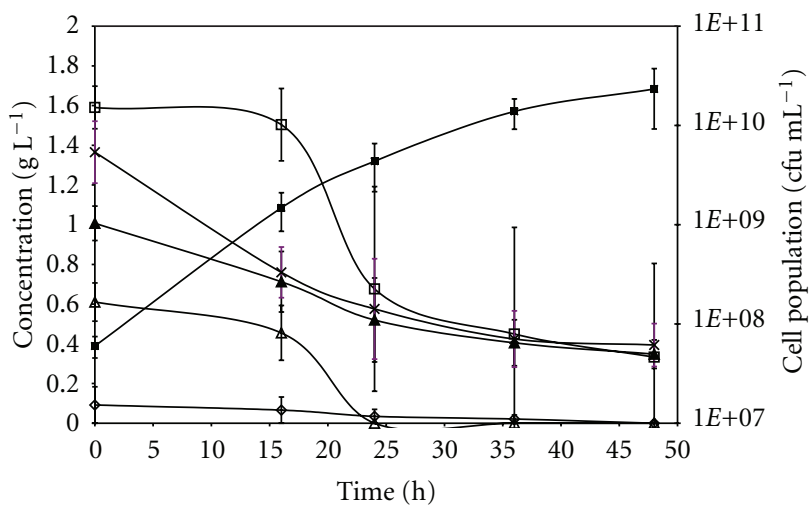

Figure 1: Average growth rate and organic acid utilization during the initial $48 \mathrm{~h}$ incubation in the CCS medium. The values for average cell count $(\boldsymbol{\square})$, acetic acid utilization $(\triangle)$, butyric acid utilization $(\diamond)$, lactic acid utilization $(\square)$ propionic acid utilization, $(\Delta)$ and succinic acid utilization $(x)$ are indicated. Values are the means of two replications with standard deviation showed by error bars.

acid consumptions were also higher in the bioreactor with the exception of lactic acid. Ammonia and phosphate usage rates were higher in bioreactor trials again due to the higher cell population.

Three ARF-feeding strategies were compared in this study. Figures 2, 3, and 4 show that ARF feeding resulted in a slight increase in cell populations. The effects of different feeding strategies on maximum cell population, and ammonia and phosphate utilization rates are shown in Table 4. The

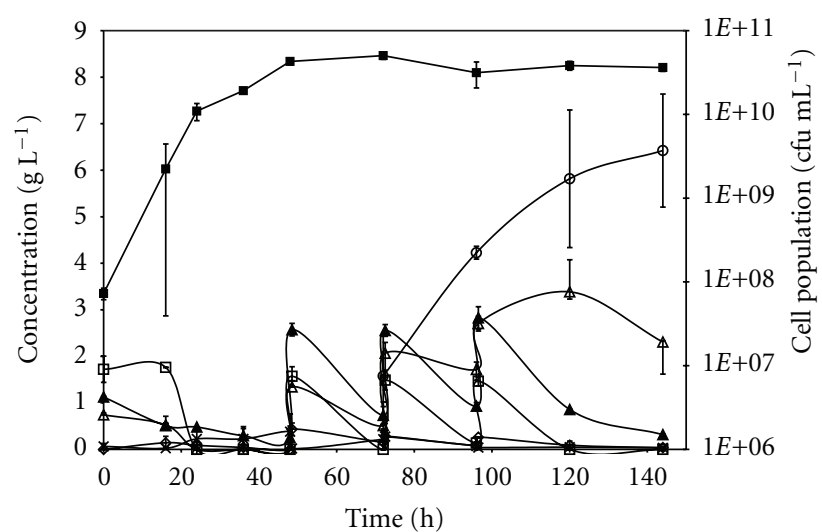

FIgure 2: Acid utilization and growth of Ralstonia eutropha with 24 $\mathrm{h}$ interval additions of ARF. The values for cell count $(\boldsymbol{\square})$, acetic acid utilization $(\triangle)$, butyric acid utilization $(\diamond)$, lactic acid utilization $(\square)$, propionic acid utilization $(\boldsymbol{\Delta})$, succinic acid utilization $(\times)$, and PHA concentration $(\mathrm{O})$ are indicated. Values are the means of two replications with standard deviation showed by error bars.

maximum cell populations were not significantly different between the three treatments. In all cases, the cell population continued to rise after ARF additions began, suggesting that the acid levels were not inhibitory. The rates of ammonia utilization and phosphate utilization were similar for all feeding strategies.

As expected, the $24 \mathrm{~h}$ addition method (Figure 2) resulted in the highest spikes in SCFA concentration, with acid levels then falling as $R$. eutropha metabolized the acids to 
TABLE 4: Comparison of all the key parameters under different ARF feeding strategies.

\begin{tabular}{|c|c|c|c|}
\hline \multirow{2}{*}{ Key parameters } & \multicolumn{3}{|c|}{ Feeding strategies } \\
\hline & $24 \mathrm{~h}$ addition & $3 \mathrm{~h}$ addition & Continuous addition \\
\hline Cell population at $48 \mathrm{~h}\left(\mathrm{CFU}^{-1} \mathrm{~mL}\right)$ & $4.28 \times 10^{10 \mathrm{a}}$ & $1.70 \times 10^{10 \mathrm{~b}}$ & $1.01 \times 10^{10 \mathrm{~b}}$ \\
\hline Maximum cell population $\left(\mathrm{CFU}^{-1} \mathrm{~mL}\right)$ & $5.03 \times 10^{10 a}$ & $5.68 \times 10^{10 a}$ & $5.47 \times 10^{10 a}$ \\
\hline Ammonia utilization rate $\left(\mathrm{g}^{-1} \mathrm{~L}^{-1} \mathrm{~h}\right)$ & $1.2^{\mathrm{a}}$ & $1.0^{\mathrm{a}}$ & $1.1^{\mathrm{a}}$ \\
\hline Phosphate utilization rate $\left(\mathrm{g}^{-1} \mathrm{~L}^{-1} \mathrm{~h}\right)$ & $0.010^{\mathrm{a}}$ & $0.013^{\mathrm{a}}$ & $0.011^{\mathrm{a}}$ \\
\hline \multicolumn{4}{|l|}{ Acid utilization $\left(\mathrm{g}^{-1} \mathrm{~L}^{-1} \mathrm{~h}\right)$} \\
\hline Acetic & $0.029^{\mathrm{a}}$ & $0.052^{\mathrm{b}}$ & $0.047^{\mathrm{b}}$ \\
\hline Butyric & $0.009^{a}$ & $0.010^{\mathrm{a}}$ & $0.014^{\mathrm{a}}$ \\
\hline Lactic & $0.074^{\mathrm{a}}$ & $0.080^{\mathrm{a}}$ & $0.078^{\mathrm{a}}$ \\
\hline Propionic & $0.077^{\mathrm{a}}$ & $0.083^{\mathrm{a}}$ & $0.080^{\mathrm{a}}$ \\
\hline Combined & $0.20^{\mathrm{a}}$ & $0.25^{\mathrm{b}}$ & $0.24^{\mathrm{b}}$ \\
\hline \multicolumn{4}{|l|}{ Fermentation efficiency (\%) } \\
\hline Acetic & $58.8^{\mathrm{a}}$ & $100^{\mathrm{b}}$ & $98.7^{\mathrm{b}}$ \\
\hline Butyric & $94.7^{\mathrm{a}}$ & $100^{\mathrm{b}}$ & $100^{\mathrm{b}}$ \\
\hline Lactic & $100^{\mathrm{a}}$ & $100^{\mathrm{a}}$ & $100^{\mathrm{a}}$ \\
\hline Propionic & $95.7^{\mathrm{a}}$ & $100^{\mathrm{b}}$ & $95^{\mathrm{a}}$ \\
\hline Combined & $82.7^{\mathrm{a}}$ & $100^{\mathrm{b}}$ & $97.8^{\mathrm{b}}$ \\
\hline \multicolumn{4}{|l|}{ PHA production } \\
\hline Cell dry weight $\left(\mathrm{g}^{-1} \mathrm{~L}\right)$ & $17.6^{\mathrm{a}}$ & $21.13^{\mathrm{a}}$ & $17.3^{\mathrm{a}}$ \\
\hline PHA concentration $\left(\mathrm{g}^{-1} \mathrm{~L}\right)$ & $6.42^{\mathrm{a}}$ & $8.37^{\mathrm{a}}$ & $6.67^{\mathrm{a}}$ \\
\hline PHA productivity $\left(\mathrm{g}^{-1} \mathrm{~L}^{-1} \mathrm{~h}\right)$ & $0.0537^{\mathrm{a}}$ & $0.0697^{\mathrm{b}}$ & $0.056^{\mathrm{a}}$ \\
\hline PHA content $(\%)$ & $36.23^{\mathrm{a}}$ & $39.52^{\mathrm{a}}$ & $37.78^{\mathrm{a}}$ \\
\hline
\end{tabular}

$\overline{\mathrm{a}, \mathrm{b}, \mathrm{c}}$ Means within column not sharing common superscript differ significantly $(P<0.05)$.

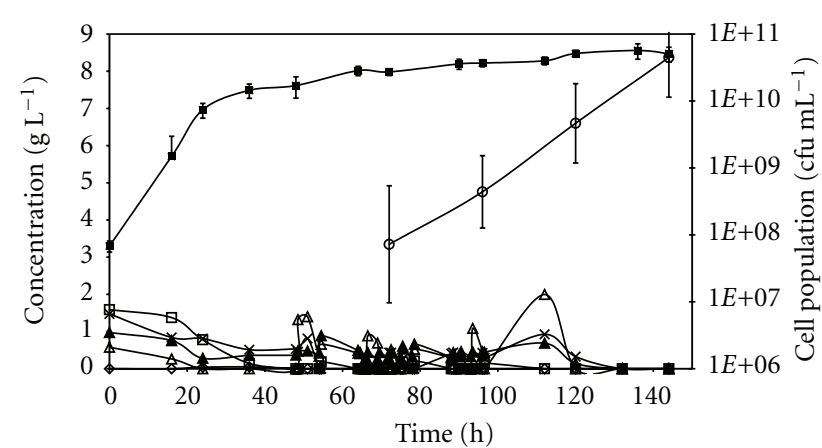

FIGURE 3: Acid utilization and growth of Ralstonia eutropha with $3 \mathrm{~h}$ interval additions of ARF. The values for cell count ( $\mathbf{\square})$, acetic acid utilization $(\triangle)$, butyric acid utilization $(\diamond)$, lactic acid utilization $(\square)$, propionic acid utilization $(\boldsymbol{\Delta})$, succinic acid utilization $(\times)$, and PHA concentration $(\mathrm{O})$ are indicated. Values are the means of two replications with standard deviation showed by error bars.

PHA. There was no apparent accumulation of lactic, butyric, or succinic acids for the $24 \mathrm{~h}$ feeding strategy. However, acetic acid $\left(2.3 \mathrm{~g} \mathrm{~L}^{-1}\right)$, and to a lesser extent propionic acid $\left(0.5 \mathrm{~g} \mathrm{~L}^{-1}\right)$, had accumulated over time. All the SCFAs were completely utilized by $144 \mathrm{~h}$ for the $3 \mathrm{~h}$ feeding strategy. For the continuous-feeding strategy, all the SCFAs were consumed by $144 \mathrm{~h}$ with the exception of propionic acid $\left(0.5 \mathrm{~g} \mathrm{~L}^{-1}\right)$.

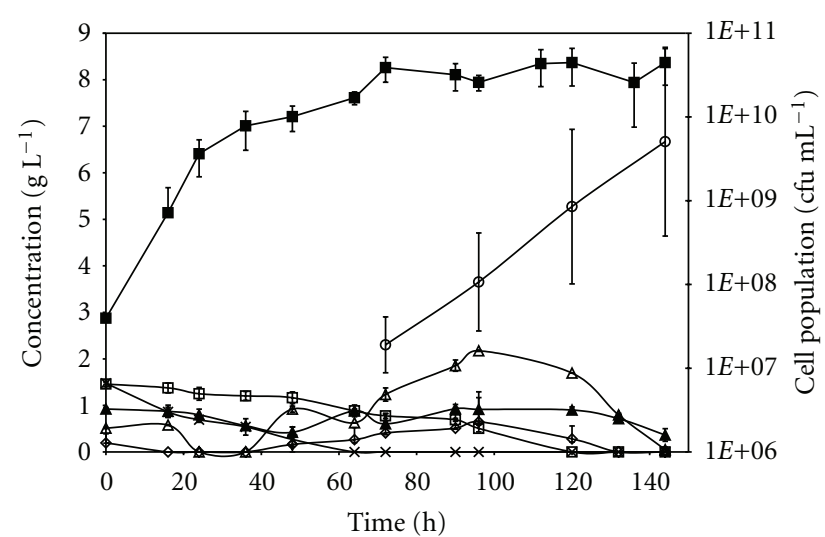

FIGURE 4: Acid utilization and growth of Ralstonia eutropha with continuous ARF addition. The values for cell count $(\boldsymbol{\square})$, acetic acid utilization $(\triangle)$, butyric acid utilization $(\diamond)$, lactic acid utilization $(\square)$, propionic acid utilization $(\boldsymbol{\Lambda})$, succinic acid utilization $(\times)$, and PHA concentration $(\mathrm{O})$ are indicated. Values are the means of two replications with standard deviation shown by error bars.

Utilization rates of the individual SCFAs during the final $96 \mathrm{~h}$ of fermentation ( 48 to $144 \mathrm{~h}$ ), along with the combined acid utilization rates, are shown in Table 4 . The combined utilization rate also included consumption of succinic acid that was already present in the CCS medium. The highest combined acid utilization rates were observed in the $3 \mathrm{~h}$ and 
TABLE 5: Comparison of combined short fatty acid feeding of Ralstonia eutropha in shake flasks.

\begin{tabular}{lcccc}
\hline \multirow{2}{*}{ Parameters } & \multicolumn{2}{c}{ Volatile fatty acid } & \\
& Acetic $\left(5 \mathrm{~g} \mathrm{~L}^{-1}\right)$ & Butyric $\left(5 \mathrm{~g} \mathrm{~L}^{-1}\right)$ & Lactic $\left(8 \mathrm{~g} \mathrm{~L}^{-1}\right)$ & Propionic $\left(5 \mathrm{~g} \mathrm{~L}^{-1}\right)$ \\
\hline Maximum cell population $\left(\mathrm{cfu} \mathrm{mL}^{-1}\right)$ & $5.70 \times 10^{9 \mathrm{a}}$ & $6.17 \times 10^{\mathrm{ab}}$ & $5.32 \times 10^{9 \mathrm{a}}$ & $6.67 \times 10^{9 \mathrm{~b}}$ \\
Fermentation efficiency $(\%)$ & $70.6^{\mathrm{a}}$ & $95.6^{\mathrm{b}}$ & $70.7^{\mathrm{a}}$ & $68.6^{\mathrm{a}}$ \\
Acid utilization rate $\left(\mathrm{g} \mathrm{L}^{-1} \mathrm{~h}^{-1}\right)$ & $0.048^{\mathrm{a}}$ & $0.041^{\mathrm{a}}$ & $0.080^{\mathrm{b}}$ & $0.046^{\mathrm{a}}$ \\
PHA concentration $\left(\mathrm{g} \mathrm{L}^{-1}\right)$ & $2.9^{\mathrm{ab}}$ & $4.6^{\mathrm{a}}$ & $2.4^{\mathrm{b}}$ & $4.3^{\mathrm{a}}$ \\
Cell dry weight $\left(\mathrm{g} \mathrm{L}^{-1}\right)$ & $9.9^{\mathrm{ab}}$ & $14.5^{\mathrm{b}}$ & $6.0^{\mathrm{a}}$ & $14.7^{\mathrm{b}}$ \\
PHA productivity $\left(\mathrm{g} \mathrm{L}^{-1} \mathrm{~h}^{-1}\right)$ & $0.024^{\mathrm{ab}}$ & $0.037^{\mathrm{a}}$ & $0.020^{\mathrm{b}}$ & $0.036^{\mathrm{a}}$ \\
PHA content $(\%)$ & $29.2^{\mathrm{a}}$ & $31.9^{\mathrm{a}}$ & $30.7^{\mathrm{a}}$ & $29.3^{\mathrm{a}}$ \\
\hline
\end{tabular}

$\overline{\mathrm{a}, \mathrm{b}}$ Means within column not sharing common superscript differ significantly $(P<0.05)$.

continuous feeding strategies, with the lowest rate in the $24 \mathrm{~h}$ feeding method.

The trend of higher acid utilization rates with the $3 \mathrm{~h}$ and continuous feeding methods also evident for the individual acids. However, the difference was only significant for acetic acid. Propionic and lactic acids were used most rapidly followed by acetic and butyric acid.

Table 4 also shows the FEs of the four SCFAs, along with the combined FE. The $3 \mathrm{~h}$ and continuous-feeding strategies resulted in the highest combined FE, while the lowest occurred with the $24 \mathrm{~h}$ feeding method. This is consistent with the lower acid utilization rates observed with the $24 \mathrm{~h}$ feeding strategy.

In comparing the individual acids, lactic acid was consumed completely, with greater than $95 \%$ utilization of propionic and butyric acids. FEs were higher for all the acids in the bioreactor trials compared to the prior shake-flask trials (Table 5).

Cell dry weights and PHA production parameters for the different ARF-feeding strategies are provided in Table 4 . The $3 \mathrm{~h}$ feeding strategy resulted in the highest cell dry weight, PHA concentration, and PHA content, but the values were not significantly different from the other feeding strategies. Only the PHA productivity for the $3 \mathrm{~h}$ feeding strategy was significantly higher. Cell dry weight and PHA production were much higher than that obtained during the shakeflask trials. The highest PHA concentration in the cells in the shake-flask trials was $4.6 \mathrm{~g} \mathrm{~L}^{-1}$ (Table 5), whereas in the fermenter trials, the PHA concentration of the cells was about 1.82 times higher [23].

\section{Discussion}

Typically, PHA production occurs during stationary phase. Hence cells are first grown through exponential phase in a balanced medium to maximize growth rate. This medium is formulated to run out of a key nutrient when the maximum cell population is achieved, then additional carbon is added by fed-batch or continuous mode to maximize PHA production [26].

In this study, nitrogen deficiency was used to trigger PHA production in the presence of excess carbon. Nitrogensupplemented CCS medium resulted in better growth of
$R$. eutropha in the bioreactors as compared to the shake flasks due to the improved aeration and agitation provided in the bioreactor, along with more consistent $\mathrm{pH}$ control. The organism continued to grow after the SCFAs were added at $48 \mathrm{~h}$. This growth was supported by the residual ammonia and phosphorus present in the medium. The organism reached its stationary phase by $96 \mathrm{~h}$ when most of the ammonia and phosphorous present in the medium were consumed. Ideally, one or both of these nutrients becomes limiting at the end of exponential phase, to trigger the shift from reproductive metabolism to PHA synthesis [26]. Because nitrogen and phosphate were not depleted until $72 \mathrm{~h}$, this could have contributed to the continued increase in cell numbers observed after $48 \mathrm{~h}$. It is likely that at least some of the SCFAs fed at $48 \mathrm{~h}$ were utilized for growth, until the point at which nitrogen became limiting. Researchers have found that the complete lack of nitrogen may suppress enzyme activity in PHA synthesis [27]. Thus, a small amount of ammonia in the media might be necessary to trigger PHA synthesis.

The utilization rate of lactic acid in the initial $48 \mathrm{~h}$ was lower than that of acetic acid probably due to higher concentration of lactic acid $\left(1.6 \mathrm{~g} \mathrm{~L}^{-1}\right)$ in the bioreactor media compared to the shake-flask media $\left(1 \mathrm{gL}^{-1}\right)$. This variation was due to the different batches of CCS obtained from the ethanol plant.

In this study, fed-batch ( $24 \mathrm{~h}$ feeding) and continuousfeeding strategies were chosen to determine their effect on PHA production. The lowest acid utilization rates and FEs were observed for the $24 \mathrm{~h}$ feeding strategy due to the periodic spikes in SCFA concentrations, that might have disrupted the acid utilization and decreased cell activity. At high SCFA concentration the $\mathrm{pH}$ of the medium can reach below the pKas for SCFAs (lactic 3.86, acetic 4.76, butyric 4.83 , and propionic 4.87). At low $\mathrm{pHs}$ the undissociated form predominates, and the SCFAs readily cross the cell membrane. Once inside, they rapidly dissociate and acidify the cytoplasm [28]. As a result, the proton gradient cannot be maintained as desired, and energy generation and transport systems dependent on proton gradient are disrupted [29]. This can also cause an increase in osmotic pressure due to the accumulation of anions [30]. At pH levels closer to the optimum for $R$ eutropha ( 7.0), SCFAs would be in the dissociated form in the medium. While the anions wouldn't 
be transported as readily, once inside the cell they would not cause the adverse effects of the undissociated form. Therefore, SCFAs can only be effective carbon sources when $\mathrm{pH}$ and SCFA concentrations are carefully regulated. Acid utilization rates might have also been reduced by depletion of certain acids at the end of each $24 \mathrm{~h}$ phase.

For the continuous strategy, small volumes of the SCFAs were fed continuously. Though FEs of the SCFAs were higher than that of the $24 \mathrm{~h}$ feeding strategy, there were slight accumulations in SCFAs towards the end of the fermentation.

It was thus necessary to develop an optimal feeding strategy which could potentially increase acid utilizations and FEs. The $3 \mathrm{~h}$ feeding strategy was thus chosen. Since the SCFAs were added in smaller doses at shorter intervals, $\mathrm{pH}$ of the medium was more efficiently regulated, which resulted in better utilization and 100\% FE of the organic acids.

In comparison to the prior aerated shake-flasks trials (Table 5), which were fed with individual SCFAs, the addition of mixed acids to the bioreactor resulted in more rapid uptake of propionic acid and slower utilization of butyric acid. Propionate utilization rate rose from $0.046 \mathrm{~g} \mathrm{~L}^{-1} \mathrm{~h}^{-1}$ in aerated shake flasks [23] to approximately $0.08 \mathrm{~g} \mathrm{~L}^{-1} \mathrm{~h}^{-1}$ when added as a part of the ARF mixture in the bioreactor trials. This was likely due to the higher cell populations achieved in the bioreactor trials coupled with the fact that proprionate utilization by $R$. eutropha is energetically favorable [31]. Moreover, addition of propionic acid in small doses might have controlled the change in $\mathrm{pH}$, and thus resulted in better utilization. The decline in the utilization rate of butyric acid, from $0.041 \mathrm{~g} \mathrm{~L}^{-1} \mathrm{~h}^{-1}$ when fed individually in aerated shake flasks to $0.011 \mathrm{~g} \mathrm{~L}^{-1} \mathrm{~h}^{-1}$ in bioreactor trials, may have been due to additional ATP needed to transport this acid $[32,33]$. Thus utilization of other acids was preferred over butyric acid when fed as a mixture for growth.

The high FEs for lactic and propionic acids were consistent with the metabolic preference of $R$. eutropha, especially considering that the ARF contained 15 and $20 \mathrm{~g} \mathrm{~L}^{-1}$ of these acids, respectively. The high FE of butyric acid may be due to the fact that ARF contained only $2 \mathrm{~g} \mathrm{~L}^{-1}$ of this acid. While conducting the shake-flask trials, we had previously noted that $R$. eutropha did not prefer acetic acid, therefore its lower FE was not surprising.

Thus, it can be concluded that in the $24 \mathrm{~h}$ strategy the sudden rise in the SCFA concentrations must have lowered the $\mathrm{pH}$ by accumulation of acid. This might have caused decrease in acid consumption, FE, and PHA productivity. Though the dosages of acids were small for the continuous feeding, continuous addition might have lowered the efficiency of the process. The smaller dosage and the fed-batch mode of the $3 \mathrm{~h}$ feeding strategy might have resulted in better control of $\mathrm{pH}$ and of catabolite repression. So the optimized growth conditions (as discussed before) for the organism and $3 \mathrm{~h}$ feeding strategy of ARF addition was considered the best to obtain optimum PHA production by the organism.

Yu et al. suggested [31] in their study that an average yield of PHA was $0.39 \mathrm{gg}^{-1}$ of carbon sources (acetic, butyric, and propionic acids). In the current study the highest yield of about $0.2 \mathrm{gg}^{-1}$ was observed when the $3 \mathrm{~h}$ feeding strategy was used. Investigators have reported that inexpensive carbon sources lead to low PHA productivity due to inefficient utilization of nutrients by organisms [3436]. A majority of carbon sources was probably utilized to generate energy for cell maintenance.

Wild-type strain of R. eutropha used in this study was not able to use glucose and did not completely utilize the high amount of glycerol present in the CCS medium. Recombinant microorganisms can be used to increase growth rate and nutrient utilization. PHA biosynthesis genes can be inserted in organisms that have wider range of utilizable substrates to increase PHA productivity and PHA content. For example, the recombinant strains of $R$. eutropha (H16) containing glucose-utilizing genes of Escherichia coli (E. coli), and E. coli harboring the R. eutropha genes had higher PHA productivity and concentration as compared to the wild-type strain $[14,34]$.

\section{Conclusion}

Since the carbon source is a major contributor to PHA cost, inexpensive sources of carbon are important. From an economical point of view, the use of purified media to increase PHA yield will significantly increase the production cost. This study showed that $R$. eutropha is capable of growing in CCS medium, a low-value byproduct of ethanol industry. We also concluded that mixture of SCFAs in the same compositional ratios of ARF was not inhibitory when added at stationary phase of growth. SCFAs can be diverted toward PHA production by R. eutropha. As the use of purified SCFAs is cost prohibitive, developing a mixed culture system to produce a mixture of SCFAs from another ethanol industry byproduct is highly cost-effective. Thus utilization of inexpensive carbon sources may lead to economically viable PHA production in future when superior genetics and fermentation strategies are applied together.

\section{Acknowledgments}

This project was funded by South Dakota Corn Utilization Council and the Agricultural Experiment Station.

\section{References}

[1] D. Byrom, "Production of poly- $\beta$-hydroxybutyrate: poly- $\beta$ hydroxyvalerate copolymers," FEMS Microbiology Reviews, vol. 103, no. 2-4, pp. 247-250, 1992.

[2] W. Amass, A. Amass, and B. Tighe, "A review of biodegradable polymers: uses, current developments in the synthesis and characterization of biodegradable polyesters, blends of biodegradable polymers and recent advances in biodegradation studies," Polymer International, vol. 47, no. 2, pp. 89-144, 1998.

[3] H. Nishida and Y. Tokiwa, "Effects of higher-order structure of poly(3-hydroxybutyrate) on its biodegradation. I. Effects of heat treatment on microbial degradation," Journal of Applied Polymer Science, vol. 46, no. 8, pp. 1467-1476, 1992.

[4] P. A. Holmes, "Biologically produced PHA polymers and copolymers," in Developments in Crystalline Polymers, D. C. Bassett, Ed., pp. 1-65, Elsevier, London, UK, 1988. 
[5] K. Lindsay, "Truly biodegradable resins are now truly commercial," Modern Plastics, vol. 396, pp. 62-64, 1992.

[6] T. V. Ojumu, J. Yu, and B. O. Solomon, "Production of polyhydroxyalkanoates, a bacterial biodegradable polymer," African Journal of Biotechnology, vol. 3, no. 1, pp. 18-24, 2004.

[7] R. J. Helleur, "Pyrolysis gas chromatography for the rapid characterization of bacterial poly ( $\beta$-hydroxybutyrate-co- $\beta$ hydroxyvalerate)," Polymer Preprints, vol. 29, pp. 609-610, 1988.

[8] U. J. Hanggi, "Pilot scale production of PHB with Alcaligenes latus," in Novel Biodegradable Microbial Polymers, E. A. Dawes, Ed., pp. 65-70, Kluwer Academic, Dordrecht, The Netherlands, 1990.

[9] M. Crank, M. Patel, F. M. Weideman, J. Schleich, B. Husing, and G. Angerer, "Techno-economic feasibility of largescale production of bio-based polymers in Europe (PROBIP)," Final Report, The European Commission's Institute for Prospective Technological Studies (IPTS), Sevilla, Spain, 2004.

[10] S. F. Williams and O. P. Peoples, "Biodegradable plastics from plants," Chemtech, vol. 26, no. 9, pp. 38-44, 1996.

[11] W. S. Ahn, S. J. Park, and S. Y. Lee, "Production of poly(3-hydroxybutyrate) by fed-batch culture of recombinant Escherichia coli with a highly concentrated whey solution," Applied and Environmental Microbiology, vol. 66, no. 8, pp. 3624-3627, 2000.

[12] D. R. Rutherford, W. J. Hammer, and G. N. Babu, "Poly( $\beta$ hydroxyorganoate) pressure sensitive adhesive compositions," U.S. Patent 5614576, 1997.

[13] M. L. Steel and P. Norton-Berry, "Non-woven fibrous materials," U.S. Patent 4603070, 1986.

[14] S. Y. Lee, "Plastic bacteria? Progress and prospects for polyhydroxyalkanoate production in bacteria," Trends in Biotechnology, vol. 14, no. 11, pp. 431-438, 1996.

[15] S. Shioya, "Optimization and control in fed-batch bioreactors," in Advances in Biochemical Engineering, A. Fichter, Ed., Springer, Berlin, Germany, 1992.

[16] G. Du and J. Yu, "Green technology for conversion of food scraps to biodegradable thermoplastic polyhydroxyalkanoates," Environmental Science and Technology, vol. 36, no. 24, pp. 5511-5516, 2002.

[17] P. Kahar, T. Tsuge, K. Taguchi, and Y. Doi, "High yield production of polyhydroxyalkanoates from soybean oil by Ralstonia eutropha and its recombinant strain," Polymer Degradation and Stability, vol. 83, no. 1, pp. 79-86, 2004.

[18] M. Koller, R. Bona, C. Hermann et al., "Biotechnological production of poly(3-hydroxybutyrate) with Wautersia eutropha by application of green grass juice and silage juice as additional complex substrates," Biocatalysis and Biotransformation, vol. 23, no. 5, pp. 329-337, 2005.

[19] C. Y. Loo, W. H. Lee, T. Tsuge, Y. Doi, and K. Sudesh, "Biosynthesis and characterization of poly(3-hydroxybutyrate-co-3hydroxyhexanoate) from palm oil products in a Wautersia eutropha mutant," Biotechnology Letters, vol. 27, no. 18, pp. 1405-1410, 2005.

[20] C. Marangoni, A. Furigo Jr., and G. M. F. Aragão, “The influence of substrate source on the growth of Ralstonia eutropha, aiming at the production of polyhydroxyalkanoate," Brazilian Journal of Chemical Engineering, vol. 18, no. 2, pp. 175-180, 2001.

[21] I. Taniguchi, K. Kagotani, and Y. Kimura, "Microbial production of poly(hydroxyalkanoate)s from waste edible oils," Green Chemistry, vol. 5, no. 5, pp. 545-548, 2003.
[22] J. Jerke, Production of pullulan by Aureobasidium pullulans using condensed corn solubles [M.S. thesis], South Dakota State University, 2001.

[23] P. Chakraborty, W. Gibbons, and K. Muthukumarappan, "Conversion of short chain fatty acids into polyhydroxyalkanoateby Ralstonia eutropha," Journal of Applied Microbiology, vol. 361, pp. 1995-2004, 2009.

[24] G. Braunegg, B. Sonnleitner, and R. M. Lafferty, "A rapid gas chromatographic method for the determination of poly $\beta$ hydroxybutyric acid in microbial biomass," European Journal of Applied Microbiology and Biotechnology, vol. 6, no. 1, pp. 2937, 1978.

[25] Y. Comeau, K. J. Hall, and W. K. Oldham, "Determination of poly- $\beta$-hydroxybutyrate and poly- $\beta$-hydroxyvalerate in activated sludge by gas-liquid chromatography," Applied and Environmental Microbiology, vol. 54, no. 9, pp. 2325-2327, 1988.

[26] L. L. Madison and G. W. Huisman, "Metabolic engineering of poly(3-hydroxyalkanoates): from DNA to plastic," Microbiology and Molecular Biology Reviews, vol. 63, no. 1, pp. 21-53, 1999.

[27] H. Shimizu, Kozaki, Y. Kodama H, and S. Shioya, "Maximum production strategy for biodegradable copolymer P, (HB-co$\mathrm{HV}$ ) in fed-batch culture of Alcaligenes eutrophus," Biotechnology and Bioengineering, vol. 62, no. 5, pp. 518-525, 1999.

[28] C. V. Salmond, R. G. Kroll, and I. R. Booth, "The effect of food preservatives on $\mathrm{pH}$ homeostasis in Escherichia coli," Journal of General Microbiology, vol. 130, no. 11, pp. 2845-2850, 1984.

[29] H. G. Lawford and J. D. Rousseau, "Effects of pH and acetic acid on glucose and xylose metabolism by a genetically engineered ethanologenic Escherichia coli," Applied Biochemistry and Biotechnology, vol. 39-40, no. 1, pp. 301-322, 1993.

[30] A. J. Roe, D. McLaggan, I. Davidson, C. O’Byrne, and I. R. Booth, "Perturbation of anion balance during inhibition of growth of Escherichia coli by weak acids," Journal of Bacteriology, vol. 180, no. 4, pp. 767-772, 1998.

[31] J. Yu, Y. Si, W. Keung, and R. Wong, "Kinetics modeling of inhibition and utilization of mixed volatile fatty acids in the formation of polyhydroxyalkanoates by Ralstonia eutropha," Process Biochemistry, vol. 37, no. 7, pp. 731-738, 2002.

[32] L. Shang, M. Jiang, and H. N. Chang, "Poly(3hydroxybutyrate) synthesis in fed-batch culture of Ralstonia eutropha with phosphate limitation under different glucose concentrations," Biotechnology Letters, vol. 25, no. 17, pp. 1415-1419, 2003.

[33] H. Shi, M. Shiraishi, and K. Shimizu, "Metabolic flux analysis for biosynthesis of poly( $\beta$-Hydroxybutyric acid) in Alcaligenes eutrophus from various carbon sources," Journal of Fermentation and Bioengineering, vol. 84, no. 6, pp. 579-587, 1997.

[34] S. Y. Lee, J. I. Choi, and H. H. Wong, "Recent advances in polyhydroxyalkanoate production by bacterial fermentation: minireview," International Journal of Biological Macromolecules, vol. 25, no. 1-3, pp. 31-36, 1999.

[35] T. Tsuge, K. Tanaka, and A. Ishizaki, "Development of a novel method for feeding a mixture of L-lactic acid and acetic acid in fed-batch culture of Ralstonia eutropha for polyD-3-hydroxybutyrate production," Journal of Bioscience and Bioengineering, vol. 91, no. 6, pp. 545-550, 2001.

[36] T. Tsuge, "Metabolic improvements and use of inexpensive carbon sources in microbial production of polyhydroxyalkanoates," Journal of Bioscience and Bioengineering, vol. 94, no. 6, pp. 579-584, 2002. 

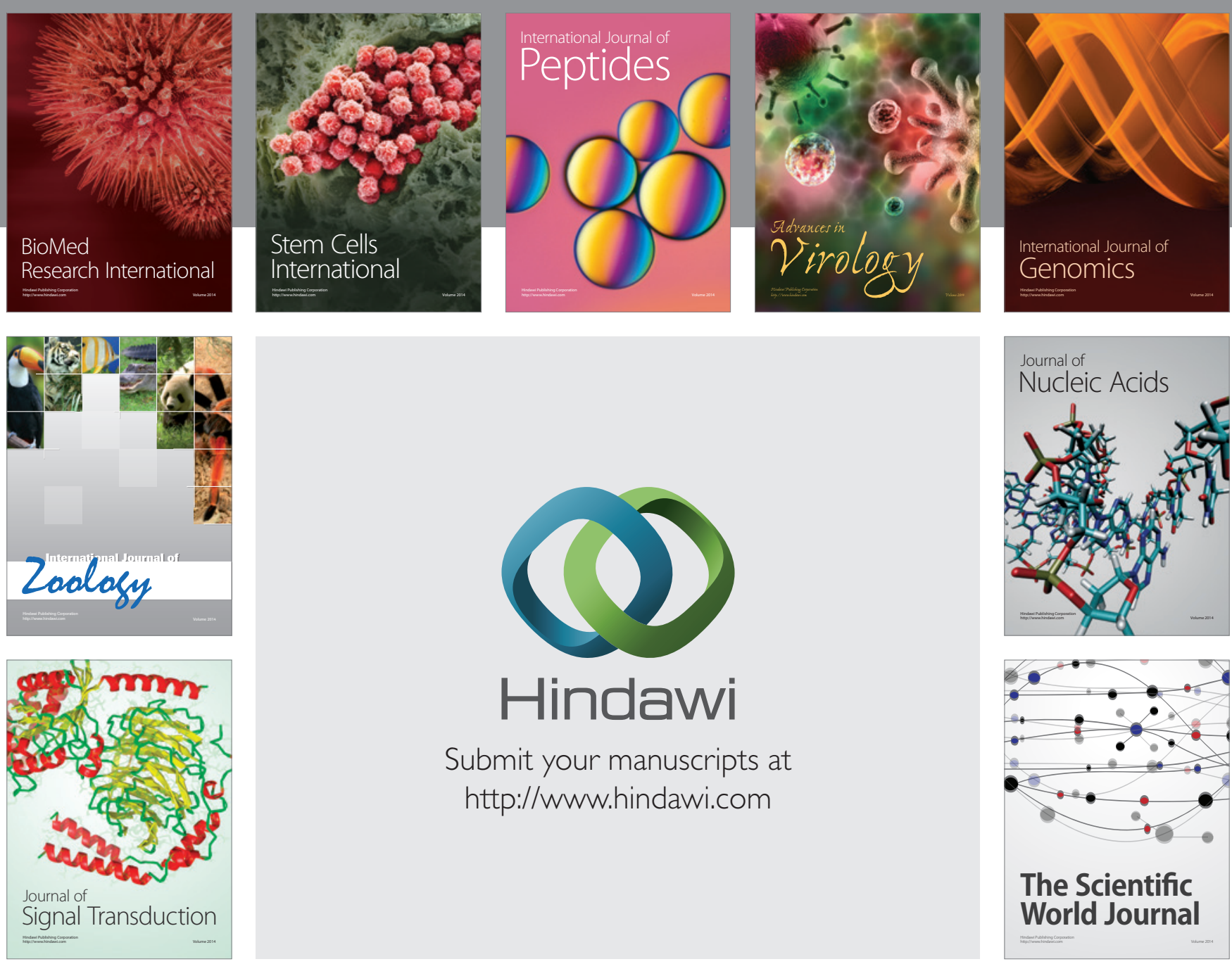

Submit your manuscripts at

http://www.hindawi.com
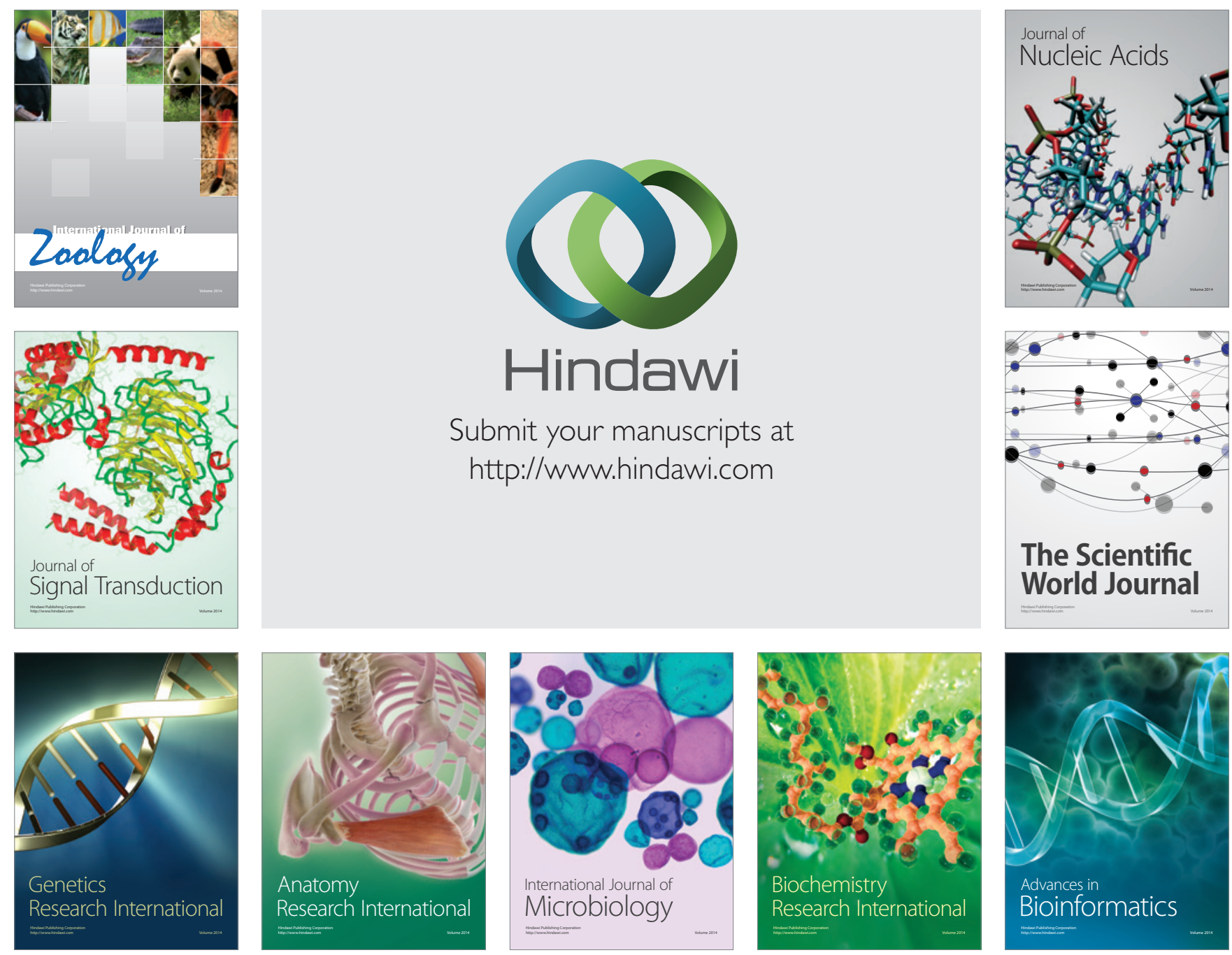

The Scientific World Journal
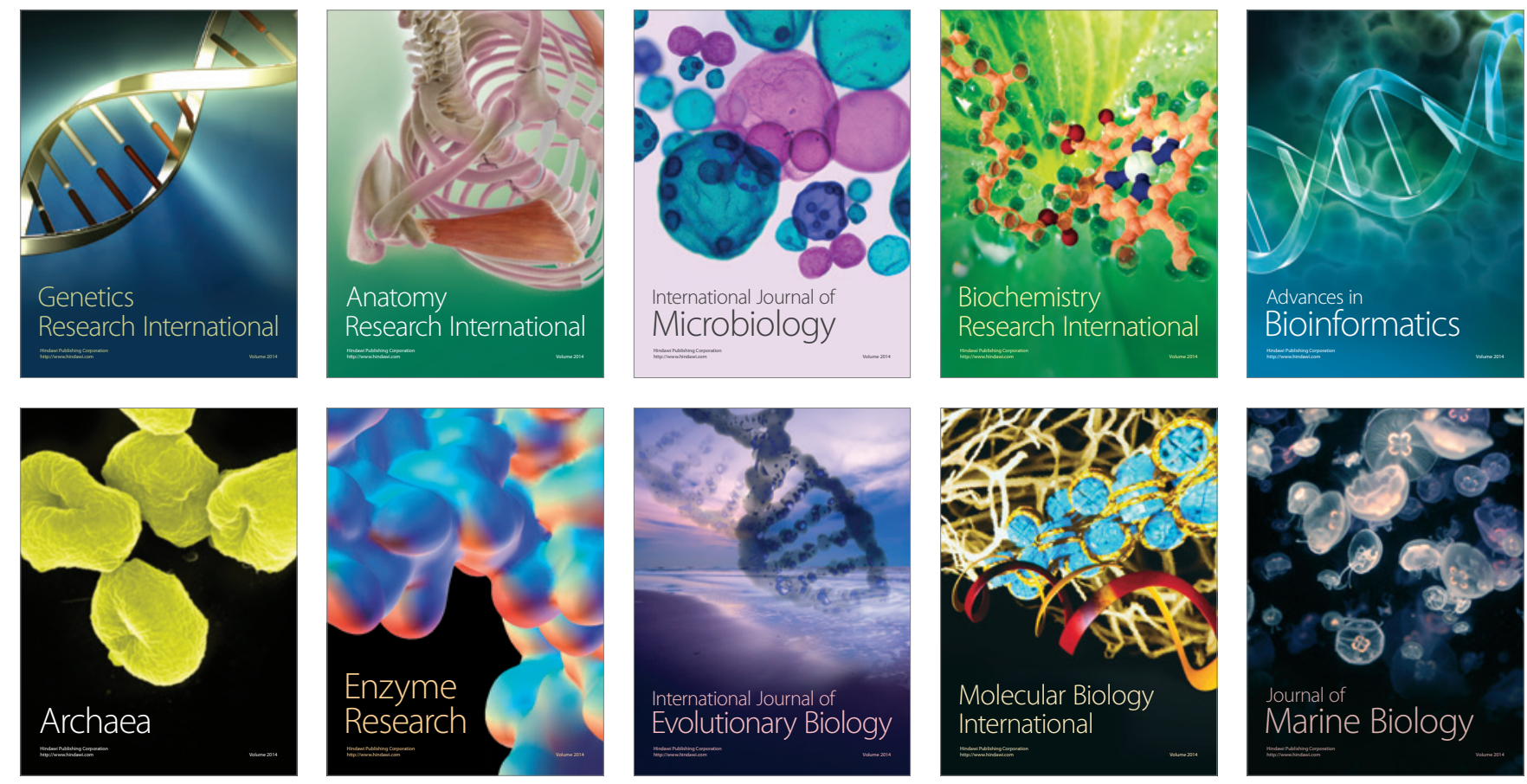